Prepared in cooperation with U.S. Fish and Wildlife Service

Examination of Movements and Survival of Pahranagat Roundtail Chub (Gila robusta jordani) in the Pahranagat River and Adjacent Waters, Nevada, 2014-18

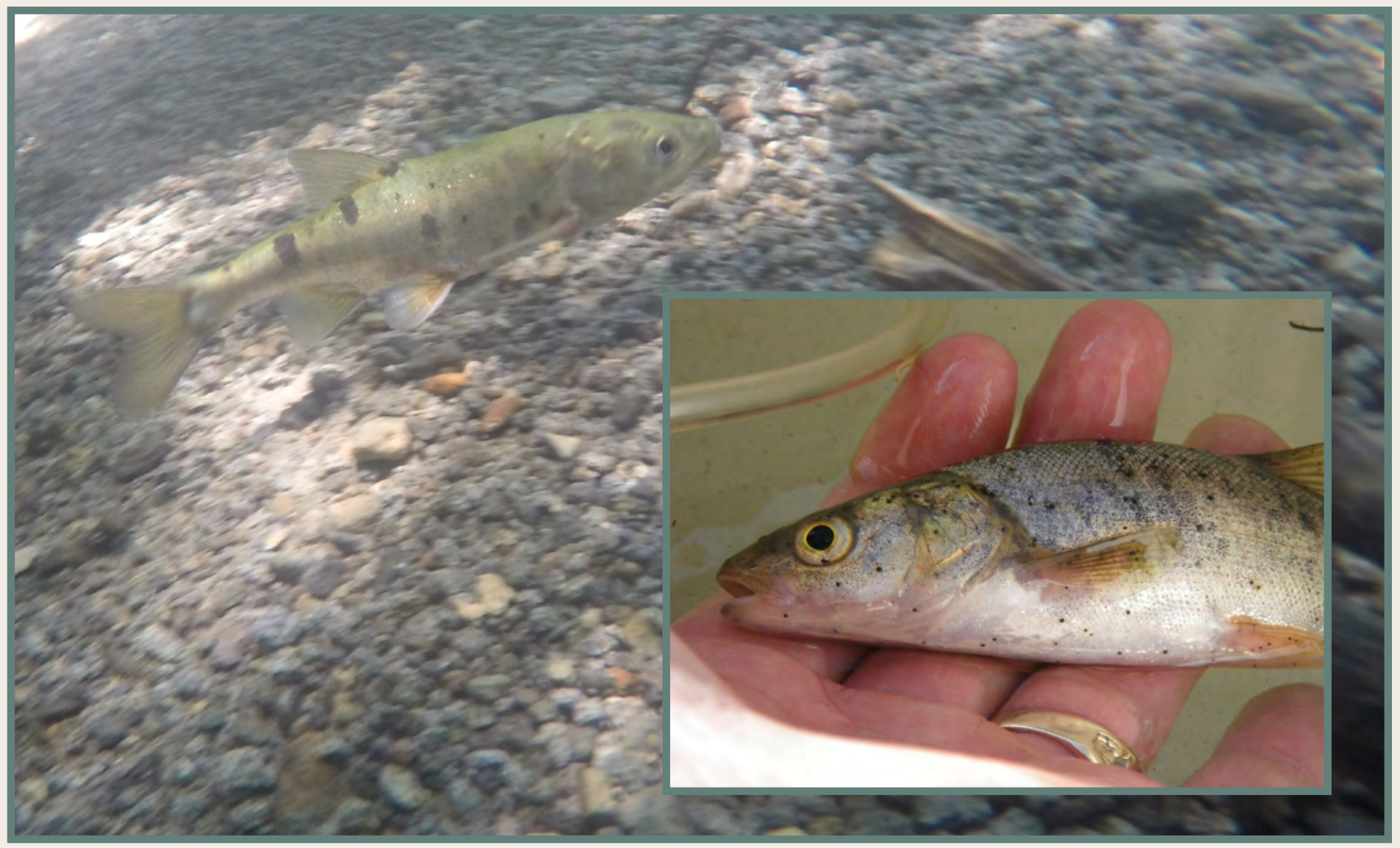

Open-File Report 2019-1075 
Cover: Photograph of Pahranagat Roundtail Chub (Gila robusta jordani). Taken by Brian Hayes, U.S. Geological Survey, October 2014. 


\section{Examination of Movements and Survival of Pahranagat Roundtail Chub (Gila robusta jordani) in the Pahranagat River and Adjacent Waters, Nevada, 2014-18}

By Barbara A. Martin, Brian S. Hayes, and Alta C. Harris

Prepared in cooperation with U.S. Fish and Wildlife Service

Open-File Report 2019-1075

U.S. Department of the Interior

U.S. Geological Survey 


\section{U.S. Department of the Interior \\ DAVID L. BERNHARDT, Acting Secretary}

U.S. Geological Survey

James Reilly, Deputy Director

U.S. Geological Survey, Reston, Virginia: 2019

For more information on the USGS—-the Federal source for science about the Earth, its natural and living resources, natural hazards, and the environment-visit https://www.usgs.gov/ or call 1-888-ASK-USGS (1-888-275-8747).

For an overview of USGS information products, including maps, imagery, and publications, visit https:/store.usgs.gov.

Any use of trade, firm, or product names is for descriptive purposes only and does not imply endorsement by the U.S. Government.

Although this information product, for the most part, is in the public domain, it also may contain copyrighted materials as noted in the text. Permission to reproduce copyrighted items must be secured from the copyright owner.

Suggested citation:

Martin, B.A., Hayes, B.S., and Harris, A.C., 2019, Examination of movements and survival of Pahranagat roundtail chub (Gila robusta jordani) in the Pahranagat River and adjacent waters, Nevada, 2014-18: U.S. Geological Survey Open-File Report 2019-1075, 23 p., https://doi.org/10.3133/ofr20191075.

ISSN 2331-1258 (online) 


\section{Contents}

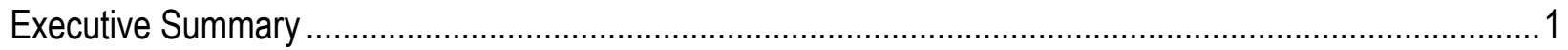

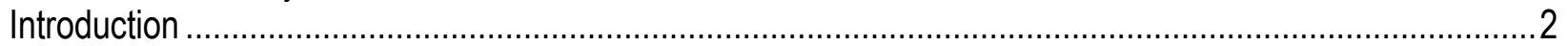

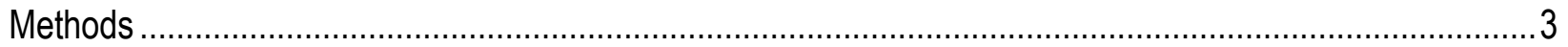

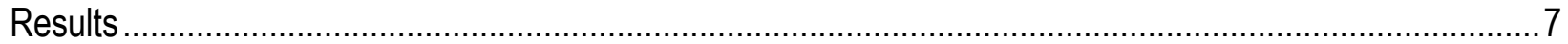

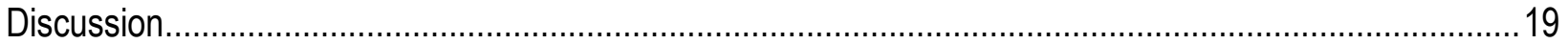

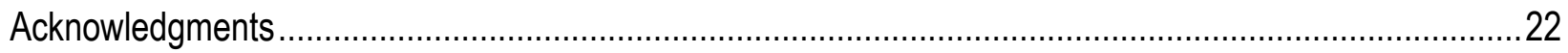

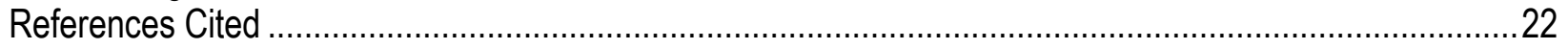

\section{Figures}

Figure 1. Map showing the location of the six passive-integrated-transponder tag antenna located on the Pahranagat River, Ditch, and Drain, Nevada ....

Figure 2. Photographs showing the location of the passive integrated transponder tag antennae located at the Fish Passage station, Pahranagat River, Nevada.

Figure 3. Graph showing number of days detected from the time of tagging to last detection for individual fish color coded for reach, Pahranagat River, Nevada, 2014-18 ................................................................. 9

Figure 4. Graph showing time scale from time of tagging to last detection for individual Pahranagat roundtail chub color coded by reach, Pahranagat River, Nevada, 2014-18.

Figure 5. Graphs showing detections of individual Pahranagat roundtail chub captured from the Pahranagat River, Nevada, 2014-15.

Figure 6. Graphs showing detections of individual Pahranagat roundtail chub captured from the Pahranagat River, Nevada, 2016.

Figure 7. Graphs showing detections of individual Pahranagat roundtail chub captured from the Pahranagat River, Nevada, 2017.

Figure 8. Graphs showing detections of individual Pahranagat roundtail chub captured from the Pahranagat

Ditch, Nevada, 2014-17.

Figure 9. Graphs showing detections of individual Pahranagat roundtail chub captured in 2018 from the

Pahranagat River and the Pahranagat Drain, Nevada, 2014-18.

Figure 10. Graphs showing population level detections of Pahranagat roundtail chub by year, month, and station,

Pahranagat River, Pahranagat Ditch, and Pahranagat Drain, 2014-18. . 18

Figure 11. Graphs showing population level diel contacts of Pahranagat roundtail chub, Pahranagat River, Pahranagat Ditch, and Pahranagat Drain, 2014-18

\section{Tables}

Table 1. Number and average total length of Pahranagat roundtail chubs captured and PIT-tagged from 2014 to 2018 by location and year, Pahranagat River, Pahranagat Ditch, and Pahranagat Drain, Nevada..

Table 2. Number of Pahranagat roundtail chubs captured from three locations with differing habitat, Pahranagat River, Pahranagat Ditch, and Pahranagat Drain, 2014-18

Table 3. Percentage of tagged Pahranagat roundtail chubs detected for less than $6,6-12,12-18$, and 18-24 months over a 2-year period, Pahranagat River, Pahranagat Ditch, and Pahranagat Drain, Nevada, 2014-18 _.....8 Table 4. Sample size, average and range of average time from tagging to last detection for each reach and year, Pahranagat River, Pahranagat Ditch, and Pahranagat Drain, Nevada, 2014-18. .

Table 5. Number and percentage of Pahranagat roundtail chub last contacted by month and season, Pahranagat

River, Pahranagat Ditch, and Pahranagat Drain, Nevada, 2014-18.

Table 6. Number and percentage of chub that were most often detected on each antenna, Pahranagat River, Pahranagat Ditch, and Pahranagat Drain, Nevada, 2014-18. 
Table 7. Number and percentage of chub recorded as their secondary location at each antenna, Pahranagat River, Pahranagat Ditch, and Pahranagat Drain, Nevada, 2014-18

Table 8. Number of Pahranagat roundtail chub detected by capture location at each of the five antennas within the Fish Passage Array, Pahranagat River, Pahranagat Ditch, and Pahranagat Drain, Nevada, 2014-18

Table 9. Number of Pahranagat roundtail chub by capture location that were last detected at each passive integrated transponder tag station, Pahranagat River, Pahranagat Ditch, and Pahranagat Drain, Nevada, 2014-18

\section{Conversion Factors}

International System of Units to Inch/pound

\begin{tabular}{lll}
\hline \multicolumn{1}{c}{ Multiply } & By & To obtain \\
\hline & Length & \\
\hline kilometer $(\mathrm{km})$ & 0.6214 & mile (mi) \\
millimeter $(\mathrm{mm})$ & 0.0394 & inch \\
\hline
\end{tabular}

Temperature in degrees Celsius $\left({ }^{\circ} \mathrm{C}\right)$ may be converted to degrees Fahrenheit $\left({ }^{\circ} \mathrm{F}\right)$ as follows:

$$
{ }^{\circ} \mathrm{F}=\left(1.8 \mathrm{x}^{\circ} \mathrm{C}\right)+32
$$

\section{Supplemental Information}

Concentrations of chemical constituents in water are given in milligrams per liter (mg/L).

\section{Abbreviations}

PIT

$\mathrm{SD}$

TL

USGS

passive integrated transponder standard deviation

total length

U.S. Geological Survey 


\title{
Examination of Movements and Survival of Pahranagat Roundtail Chub (Gila robusta jordani) in the Pahranagat River and Adjacent Waters, Nevada, 2014-18
}

\author{
By Barbara A. Martin, Brian S. Hayes, and Alta C. Harris
}

\section{Executive Summary}

The Pahranagat roundtail chub (Gila robusta jordani; hereinafter "chub") was federally listed as endangered in 1970 (U.S. Fish and Wildlife Service, 1970). In the decades following the listing, the chub has declined to extremely low numbers (Tuttle and others, 1990; Guadalupe, 2014). Loss of available habitat appears to be one of the main reasons for the decline of this species. Historically, the chub are assumed to have had approximately 30 kilometers $(\mathrm{km})$ of habitat available to them, whereas currently they appear to primarily occupy $3.5 \mathrm{~km}$ of the Pahranagat River, up to $2.5 \mathrm{~km}$ of the Pahranagat Ditch, and a small portion of the Pahranagat Drain. Each year in mid-March, a gate at the top of the fish passage structure is closed to divert water down the Pahranagat Ditch, almost completely eliminating any flow into the Pahranagat Drain. The gate is usually removed in midOctober, allowing for flow to reoccur in the Pahranagat Drain. Due to the intermittent nature of the Pahranagat Drain, it is considered a sink for the species, and yearly salvage operations are conducted to remove chub from the Pahranagat Drain. The lower portion of the Pahranagat Ditch is also thought to be a sink for the species, due to high flows and limited structure potentially pushing the chub out of the system. Movements of passive-integrated-transponder (PIT) tagged chub indicate that adults and larger juveniles are not likely to be swept downstream to the point of exiting the system; however, the smaller juveniles and larvae are likely to be entrained in the Pahranagat Drain and possibly the lower portion of the Pahranagat Ditch. Only 2 of 64 PIT-tagged chub (3 percent) were observed to exit the system through the Pahranagat Ditch as they were last recorded on the Lower Ditch antenna. No PITtagged chub was observed exiting the system through the Pahranagat Drain.

Although capture location was a good predictor of where PIT tagged fish were primarily detected, fish were observed to meander throughout the available habitat. Chub captured and released in the Pahranagat River were detected more often in the upper portion of the Pahranagat River, whereas chub captured and released in the Pahranagat Ditch were more often detected in and near the Pahranagat Ditch. This suggests some degree of site fidelity. However, the two chub that were captured in the Pahranagat Drain and relocated into the middle portion of the Pahranagat River near the Between Bridges antenna were not able to get back to the closed off Pahranagat Drain (closed to fish passage from mid-March through mid-October), but were primarily detected in and near the Pahranagat Ditch. Movements from one end of the system to the other end of the system $(3.5 \mathrm{~km})$ could occur within a day and there were no observed seasonal location preferences for the chubs. However, there was more activity in the uppermost sites during fall and winter, presumedly associated with spawning. Furthermore, chub were found to be more active during the daylight hours in fall and winter verses spring and summer. During summer, chubs were the least active, especially during daylight hours. 
Most of the fish tagged were estimated to be adults based on size; 84 percent of fish tagged in this study were greater than 100 millimeters (mm) total length (TL). One chub monitored during this study (139 $\mathrm{mm}$ TL when tagged) was observed for a total of 714 days following capture, indicating that chub can survive at least 3 years. Furthermore, two fish greater than $200 \mathrm{~mm}$ TL when tagged were detected for another 7 months after tagging, which supports life history descriptions in the Recovery Plan that states Pahranagat roundtail chub can reach $250 \mathrm{~mm}$ TL (U.S. Fish and Wildlife Service, 1998). In addition to natural mortality events, fish may die from extreme temperatures or other environmental stressors. None of the fish tagged in 2014 or 2015 were detected past August 31, 2016, which suggests that there may have been some external influence causing mortality of the few remaining fish from May 1, 2016, to August 31, 2016. Although habitat for chub has been limited for decades to a very small section of the Pahranagat River and the Pahranagat Ditch (U.S. Fish and Wildlife Service, 1998), this study suggests that recent declining numbers of chub are most likely due to mortality events and not due to the fish emigrating from the system through the Pahranagat Ditch or the Pahranagat Drain.

\section{Introduction}

Pahranagat roundtail chub (Gila robusta jordani; hereinafter "chub") is one of three endemic fishes federally listed as endangered in the Pahranagat Valley in Lincoln County, Nevada (U.S. Fish and Wildlife Service, 1998). The chub were first collected in 1938 by Miller and Hubbs (1960) from Crystal Springs. They were rediscovered and described in 1949 by Tanner (1950) on the Whipple Ranch in the outflow of Hiko Spring. The chub are believed to mature at about 2-3 years and potentially live up to 7 years (U.S. Fish and Wildlife Service, 2014). Adults are generally greater than 100 millimeters (mm) total length (TL) and have been recorded up to 250 (U.S. Fish and Wildlife Service, 1998). Sigler (1987) indicated that the chub probably lives 3-5 years. Hence, the U.S. Fish and Wildlife Service (1998) has listed a requirement of three or more year classes as an indicator of the species recovery. Tanner (1950) predicted that the species would become extinct in the near future because of the scarcity of the chub and the water usage practices associated with the springs in the area. The chub are no longer found in these two habitats. Although there are no historical records of the species abundance, there are anecdotal reports that the fish were used for aquaculture and as a food source and therefore, are assumed to have been historically abundant (U.S. Fish and Wildlife Service, 1998). The decline of these species has been attributed to habitat destruction and the introduction of exotic fishes.

Due to water diversions for irrigation and manipulation of aquatic habitat for over a century, well before the first fish surveys were conducted, little is known about pre-manipulation distribution and abundance of chub (U.S. Fish and Wildlife Service, 1998). Chub are expected to have once inhabited all major waters (about 30 kilometers of habitat, primarily in the Pahranagat River) in the Pahranagat Valley (U.S. Fish and Wildlife Service, 1998). Currently, the chub inhabit approximately 3.5 kilometers $(\mathrm{km})$ of the remaining $20 \mathrm{~km}$ of the Pahranagat River and to a lesser extent the upper $2.5 \mathrm{~km}$ of a $14.2 \mathrm{~km}$ irrigation ditch (Pahranagat Ditch) just downstream of the Pahranagat River. Chub can also be found in the upper portion (approximately $1 \mathrm{~km}$ ) of a $5.6 \mathrm{~km}$ intermittent drain (Pahranagat Drain), located in the old river channel, that veers off to the east from the Pahranagat River downstream of the Fish Passage Barrier installed in 2012. Each year in mid-March, a gate above the Fish Passage Barrier is closed to divert water down the Pahranagat Ditch. This gate remains closed through the irrigation season until mid-October. The Pahranagat Drain only receives a small amount of water throughout the summer due to a leaky diversion, and any chub stranded in the drain cannot access the river during the irrigation season. Many juveniles use the upper part of the Pahranagat Drain as habitat, become stranded, and must be salvaged and translocated to the Pahranagat River. 
Chub are often found in habitat with hard cobble substrate and can be found in pools below a riffle, deeper pools, closer to the stream bottom, and in faster water (Tuttle and others, 1990; Guadalupe, 2014). Habitat differs among the three locations. The Pahranagat River has a dense riparian corridor of ash and willows bordering most of the stream. Substrate varies depending on the reach and is comprised of cobble, gravel, sand, silt, and clay. The Pahranagat Ditch is a concrete channel with no riparian corridor. Sections of the Pahranagat Ditch have broken concrete creating artificial pools that provide refugium for the chub from high flows that occur in other sections of the Pahranagat Ditch. The Pahranagat Drain has an intermittent riparian corridor composed of ash and willow. The substrate is primarily sand and silt (Tuttle and others, 1990).

The chub was listed as endangered in 1970 (U.S. Fish and Wildlife Service, 1970). From 1986 to 1989, it was estimated that there were 150-260 adults (Tuttle and others, 1990). In May 2014, a total of 99 chub, including 44 young-of-year fish, were observed during a snorkel survey of the Pahranagat River, the highest number observed since 2006 when 84 were observed (Guadalupe, 2014). In April 2014, 100 young-of-year chub were translocated to the survey area from the Pahranagat Drain, downstream of the Fish Passage Barrier, and these introduced fish probably contributed to the large number of young-of-year fish observed during the 2014 survey. The Pahranagat Drain has been considered as a sink for the species due to chub becoming stranded when the Pahranagat Drain dries up during the summer. In addition, it has been hypothesized that chub that travel too far downstream in the Pahranagat Ditch may not be able to get back upstream due to high flows and little structure. If stranding does occur the Pahranagat Ditch may also reduce the survival of the chub. This year-round movement study of tagged Pahranagat roundtail chubs had two primary objectives: (1) determine if chub exhibited seasonal or site preferences in three distinct reaches within the Pahranagat Valley (River, Ditch, and Drain); (2) identify when chub were no longer detected and if fish were pushed downstream into unsuitable habitat of the Pahranagat Drain or the lower part of the Pahranagat Ditch.

\section{Methods}

In December 2014, PIT-tag antennas were installed at three locations throughout the Pahranagat River (Ash Creek, Upper Bridge, Lower Bridge) and one downstream location on the Pahranagat Ditch (Lower Ditch: fig. 1). Furthermore, an antenna array was set up near the Fish Passage Barrier (Fish Passage) in December 2014. An additional antenna was deployed between the Upper and Lower Bridges (Between Bridges) in April 2015. Each station was equipped with a single antenna, with the exception of the Fish Passage station, which had five antennas designed to assess directionality of fish movements, towards the Pahranagat Drain or the Pahranagat Ditch. The five antennas at the Fish Passage station were placed in the pond located at the head of the Pahranagat Ditch (Pond: F1), in the Pahranagat Ditch downstream of the pond (Upper Ditch: F2), at the most upstream (Upstream Barrier: F3) and most downstream (Downstream Barrier: F4) ends of the Fish Passage Barrier located on the Pahranagat Drain, and in the Pahranagat Drain directly below the Fish Passage Barrier (Upper Drain: F5: fig. 2). 


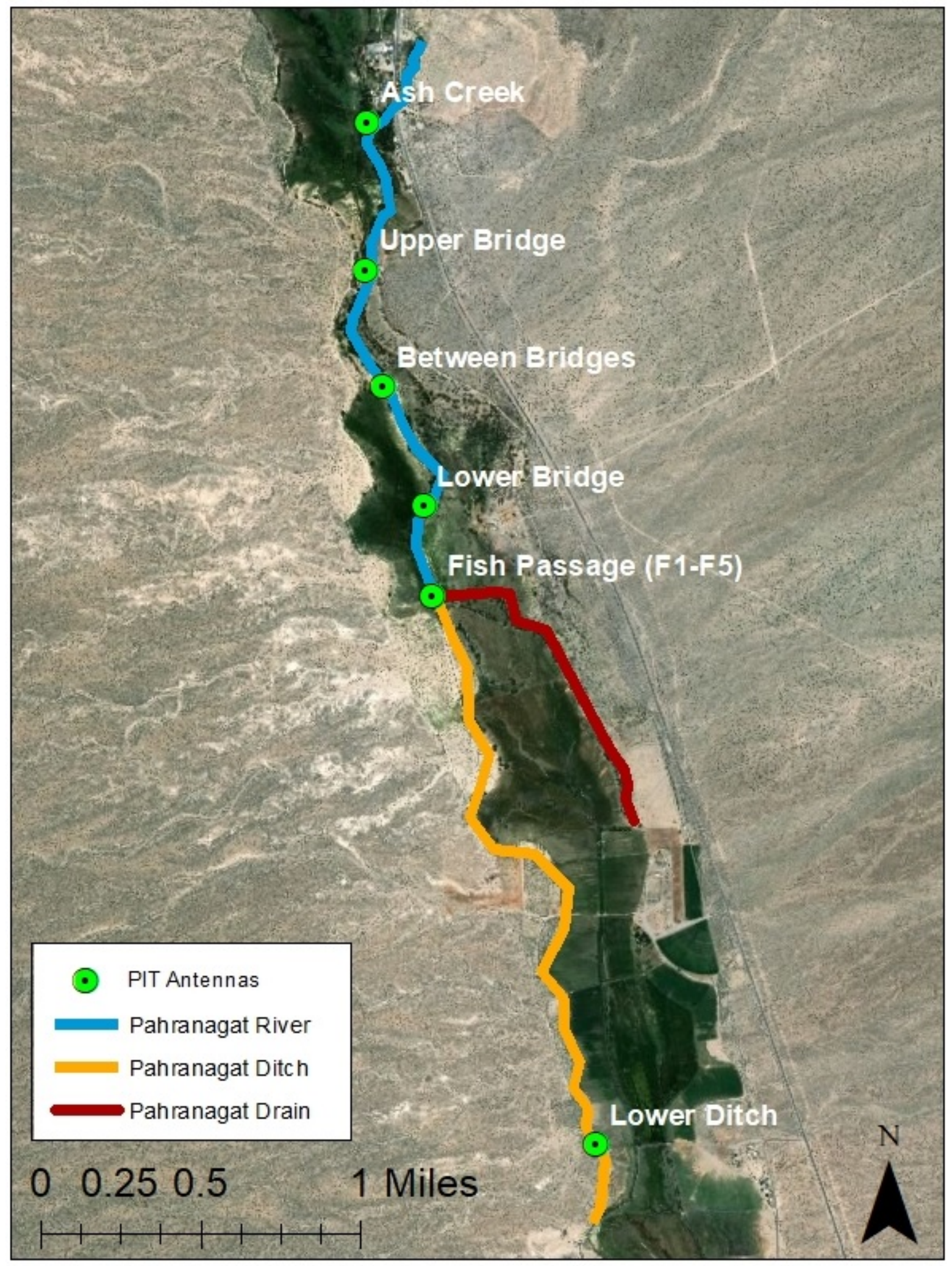

Figure 1. Map showing the location of the six passive-integrated-transponder (PIT) tag antenna located on the Pahranagat River, Ditch, and Drain, Nevada. 


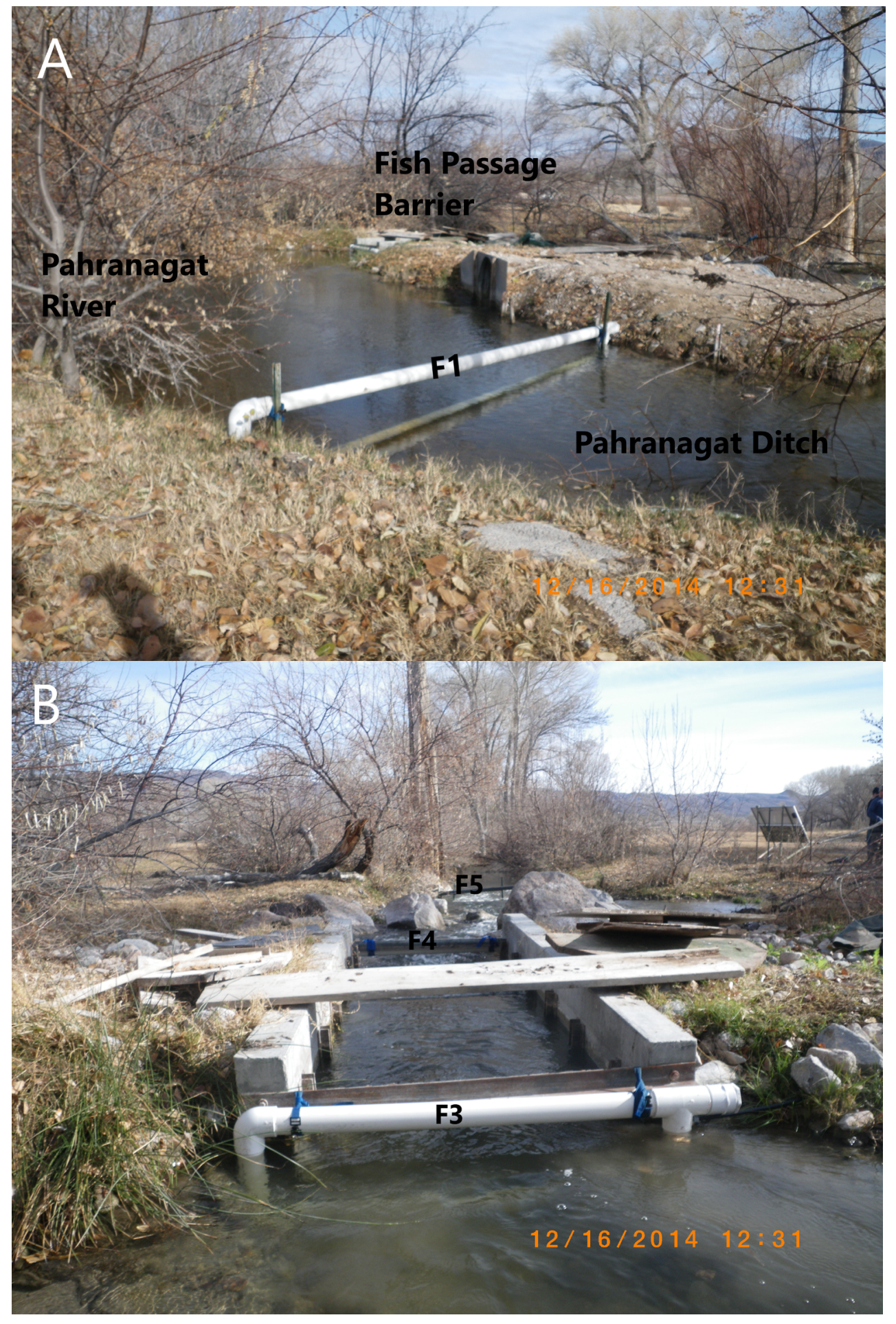

Figure 2. Photographs showing the location of the passive integrated transponder tag antennae located at the Fish Passage station, Pahranagat River, Nevada. (A) F1 antenna at the pond located at the upper ditch in the foreground and the Fish Passage Barrier in the background, with the Pahranagat River coming in from the left and the F2 antenna off to the right (not shown). (B) top of the Fish Passage Barrier in the foreground and its associated F3 antenna, the bottom of the Fish Passage Barrier and its associated F4 antenna are located midpicture, and the drain below the Fish Passage Barrier and its associated F5 antenna is in the background. 
From 2014 to 2018, 62 chub were captured (via dip net, hoop net, and electrofishing) from the Pahranagat River and the Pahranagat Ditch, tagged with passive integrated transponders (PIT) tags (134.2 kHz full-duplex tags), and released in the vicinity of capture (table 1; fig. 1). Additionally, two chubs salvaged from the Pahranagat Drain in 2018 were PIT-tagged, translocated, and released in the Pahranagat River near the Between Bridges antenna (fig. 1). Due to the lower read range of the smaller PIT tags, it was originally planned that only juveniles (less than $100 \mathrm{~mm}$ TL) would receive the 8 and $9 \mathrm{~mm}$ tags; however, there were instances when the field crews had no choice on tag size, so some adults were also tagged with the smaller tags. All detections throughout the study were remotely recorded on cheese blocks (FS2001F Portable Reader) at each, station except those at the Fish Passage station which were remotely recorded on a master controller (Biomark IS1001). Attempts were made to keep the antennas running year-round, but there were periods when individual antennas were down and detections of fish could have been missed.

Table 1. Number and average ( \pm standard deviation) total length $(\mathrm{mm})$ of Pahranagat roundtail chubs (Gila robusta jordani) captured and PIT-tagged from 2014 to 2018 by location and year, Pahranagat River (River), Pahranagat Ditch (Ditch), and Pahranagat Drain (Drain), Nevada.

[Abbreviation: SD, standard deviation; TL, total length; mm, millimeter]

\begin{tabular}{|c|c|c|c|c|c|c|c|}
\hline \multirow[b]{2}{*}{ Year } & \multirow[b]{2}{*}{ Months } & \multirow[b]{2}{*}{ Location } & \multirow{2}{*}{$\begin{array}{l}\text { Average } \pm \text { SD TL mm } \\
\text { (range) }\end{array}$} & \multicolumn{3}{|c|}{ Tag size } & \multirow[b]{2}{*}{ Total } \\
\hline & & & & $8 \mathrm{~mm}$ & $9 \mathrm{~mm}$ & $12 \mathrm{~mm}$ & \\
\hline \multirow[t]{2}{*}{2014} & \multirow[t]{2}{*}{ October and November } & River & $124 \pm 45(81-206)$ & & 4 & 5 & 9 \\
\hline & & Ditch & $168 \pm 32(110-213)$ & & 1 & 8 & 9 \\
\hline \multirow[t]{2}{*}{2015} & \multirow{2}{*}{$\begin{array}{l}\text { February, March, May, } \\
\text { November, December }\end{array}$} & River & $149 \pm 18(121-173)$ & & & 8 & 8 \\
\hline & & Ditch & & & & & 0 \\
\hline \multirow[t]{2}{*}{2016} & \multirow[t]{2}{*}{ November and December } & River & $126 \pm 23(89-165)$ & & 3 & 9 & 12 \\
\hline & & Ditch & 120 & & & 1 & 1 \\
\hline \multirow[t]{2}{*}{2017} & \multirow{2}{*}{$\begin{array}{l}\text { January, November, and } \\
\text { December }\end{array}$} & River & $113 \pm 23(71-155)$ & 5 & 7 & 7 & 19 \\
\hline & & Ditch & 172 & & & 1 & 1 \\
\hline \multirow[t]{3}{*}{2018} & May and June & River & $124 \pm 11(116-131)$ & & 3 & & 3 \\
\hline & & Ditch & & & & & 0 \\
\hline & & Drain & $169 \pm 21(154-184)$ & & & 2 & 2 \\
\hline
\end{tabular}

In order to not unduly bias encounters of individuals at detection stations, data of remote detections were filtered for all analysis to no more than one detection per minute per fish at a particular station. Graphs of detections of individual chub over a condensed timescale were created by plotting these detections over time, with lighter circles indicating individual detections and darker circles indicating overlapping detections for each station. Therefore, the intensity of the color indicates the relative amount of time that a particular fish spent at a given station over time. For the graphs of overall activity level for all chubs combined, the data was summarized by using the filtered data mentioned above summed over an hour for each individual fish and then further combining all fish encounters at a station by hourly time spans. Analysis of movements of fish located at the Fish Passage array were likewise filtered to one detection per minute on any given antenna. Summations of last detection location of individual fish was based on individuals that were detected at least 7 days past tagging in order to not bias the results due to potential tagging mortality. Furthermore, the dataset of last detections was truncated to exclude fish that were still detected at the end of the study, because they still had the potential of being detected again and the lack of detection may not have been associated with mortality. 


\section{Results}

Sixty-four chub were captured and tagged from 2014 to 2018: 51 in the River, 11 in the Ditch, and 2 in the Drain (table 2). Individuals ranged in size from 71 to $213 \mathrm{~mm}$ TL and averaged $133 \mathrm{~mm}$ (table 2). Although the overall size ranges were similar among habitats, the average size was smallest in the River, intermediate in the Ditch, and largest in the Drain (table 2). Three fish were recaptured in the same season and found in their original capture location (two in the Ditch and one in the River). A fourth individual was tagged in 2016 and then recaptured twice in 2017 (all from the River). All other encounters with individual fish were detections recorded by PIT-tag antennas.

Table 2. Number of Pahranagat roundtail chubs (Gila robusta jordani) captured from three locations with differing habitat, Pahranagat River (River), Pahranagat Ditch (Ditch), and Pahranagat Drain (Drain), 2014-18.

[Average total length and average time from tagging to last detection (days at large) followed by standard deviation and ranges are given for each general location. Abbreviations: TL, total length; SD, standard deviation; mm, millimeter]

\begin{tabular}{llcc}
\hline Location & Number of fish & TL mm, Average \pm SD (range) & Days at large, Average \pm SD (range) \\
\hline River & 51 & $124 \pm 29(71-206)$ & $220 \pm 208(0-714)$ \\
Ditch & 11 & $158 \pm 44(64-213)$ & $240 \pm 209(0-609)$ \\
Drain & 2 & $169 \pm 21(154-184)$ & $53 \pm 74(1-106)$ \\
\hline
\end{tabular}

The average time from tagging to last detection (Days at Large) for all 64 chub was 218 days (7 months) and ranged from 0 to 714 days. The majority of fish were detected for less than 6 months after tagging, with no relationship between TL at capture and Days at Large (table 3). Chub captured in the River and the Ditch had similar average durations for Days at Large (table 2; fig. 3). Seven fish were never detected by any antenna after release. Of these, four fish were tagged and released in 2014, 1-2 months before PIT-tag antennas were installed (two from the River and two from the Ditch). One of these four 2014 fish was recaptured 2 weeks after it was initially captured but prior to the installation of the PIT-tag antennas (both times captured in the Ditch). The remaining three fish were captured from the River (February 2015, March 2015, and November 2017). Two fish were detected a day after tagging with the last detection at the Fish Passage array (one from the Drain and one from the River). An additional six chub (from the River) were detected within a week after tagging and then never detected again (one at Between Bridges, three at Lower Bridge, and two at Fish Passage). Chub that were salvaged from the Drain were detected fewer days after tagging than fish from the other two groups (table 2). However, chubs were only captured from the Drain in $2018(n=2)$, and one of the two fish had a similar detection duration as that of one of the River fish caught in 2018, while the other fish was only detected 1 day after being tagged (fig. 4). Although average Days at Large appeared different among years, the large standard errors made the differences not statistically significant (table 4). None of the chub tagged in 2014 and 2015 were detected after August 31, 2016, which suggests chub tagged in 2014 and 2015 did not survive past that date (fig. 4). However, only four of the chub tagged in 2014 and 2015 were still detected on or after July 15, 2016. As of October 1, 2018, seven fish were detected from the fish tagged in 2016, 2017, and 2018. The majority of the chubs that were detected at least 1 week after release, excluding fish still detected at the end of the study, were last detected during winter (30 percent; table 5). 
Table 3. Percentage of tagged Pahranagat roundtail chubs (Gila robusta jordani) detected for less than 6, 6-12, 12-18, and 18-24 months over a 2-year period, Pahranagat River, Pahranagat Ditch, and Pahranagat Drain, Nevada, 2014-18.

[Average total length followed by standard deviation and ranges are given for the fish that fell into each time frame. Abbreviations: mm, millimeter; SD, standard deviation; TL, total length; $<$, less than]

\begin{tabular}{lcc}
\hline Duration & Percent of fish detected & TL in mm, Average \pm SD (range) \\
\hline$<6$ months & 52 & $130 \pm 34(64-193)$ \\
$6-12$ months & 27 & $137 \pm 40(80-213)$ \\
$12-18$ months & 12 & $131 \pm 30(89-172)$ \\
$18-24$ months & 9 & $126 \pm 29(89-165)$ \\
\hline
\end{tabular}

Table 4. Sample size, average ( \pm standard deviation) and range of average time from tagging to last detection (Days at Large) for each reach and year, Pahranagat River, Pahranagat Ditch, and Pahranagat Drain, Nevada, 2014-18.

[Locations shown in figure 1. Abbreviation: N, standard size]

\begin{tabular}{|c|c|c|c|c|c|}
\hline Location & 2014 & 2015 & 2016 & 2017 & 2018 \\
\hline \multirow[t]{2}{*}{ River } & $323 \pm 241(0-651)$ & $161 \pm 155(0-371)$ & $294 \pm 281(3-714)$ & $178 \pm 137(0-138)$ & $46 \pm 74(3-131)$ \\
\hline & $\mathrm{N}=9$ & $\mathrm{~N}=8$ & $\mathrm{~N}=12$ & $\mathrm{~N}=19$ & $\mathrm{~N}=3$ \\
\hline \multirow[t]{2}{*}{ Ditch } & $206 \pm 206(0-609)$ & & 538 & 243 & \\
\hline & $\mathrm{N}=9$ & & $\mathrm{~N}=1$ & $\mathrm{~N}=1$ & \\
\hline \multirow[t]{2}{*}{ Drain } & & & & & $53 \pm 74(1-106)$ \\
\hline & & & & & $\mathrm{N}=2$ \\
\hline
\end{tabular}

Table 5. Number and percentage of Pahranagat roundtail chub (Gila robusta jordani) last contacted by month and season, Pahranagat River, Pahranagat Ditch, and Pahranagat Drain, Nevada, 2014-18.

[Only chub detected on remote detection antennas at least 7 days after release were included. The seven fish detected in October, 2018 (end of the study) were not included]

\begin{tabular}{llllllll}
\hline Month/season & $\begin{array}{l}\text { Number } \\
\text { (percent) }\end{array}$ & Month/season & $\begin{array}{l}\text { Number } \\
\text { (percent) }\end{array}$ & Month/season & $\begin{array}{l}\text { Number } \\
\text { (percent) }\end{array}$ & Month/season & $\begin{array}{l}\text { Number } \\
\text { (percent) }\end{array}$ \\
\hline January & $4(10.0)$ & April & $3(7.5)$ & July & $3(7.5)$ & October & $2(5.0)$ \\
February & $5(12.5)$ & May & $6(15.0)$ & August & $5(12.5)$ & November & $2(5.0)$ \\
March & $3(7.5)$ & June & $1(2.5)$ & September & $2(5.0)$ & December & $4(10.0)$ \\
\hline Winter & $12(30)$ & Spring & $10(25)$ & Summer & $10(25)$ & Fall & $8(20)$ \\
\hline
\end{tabular}




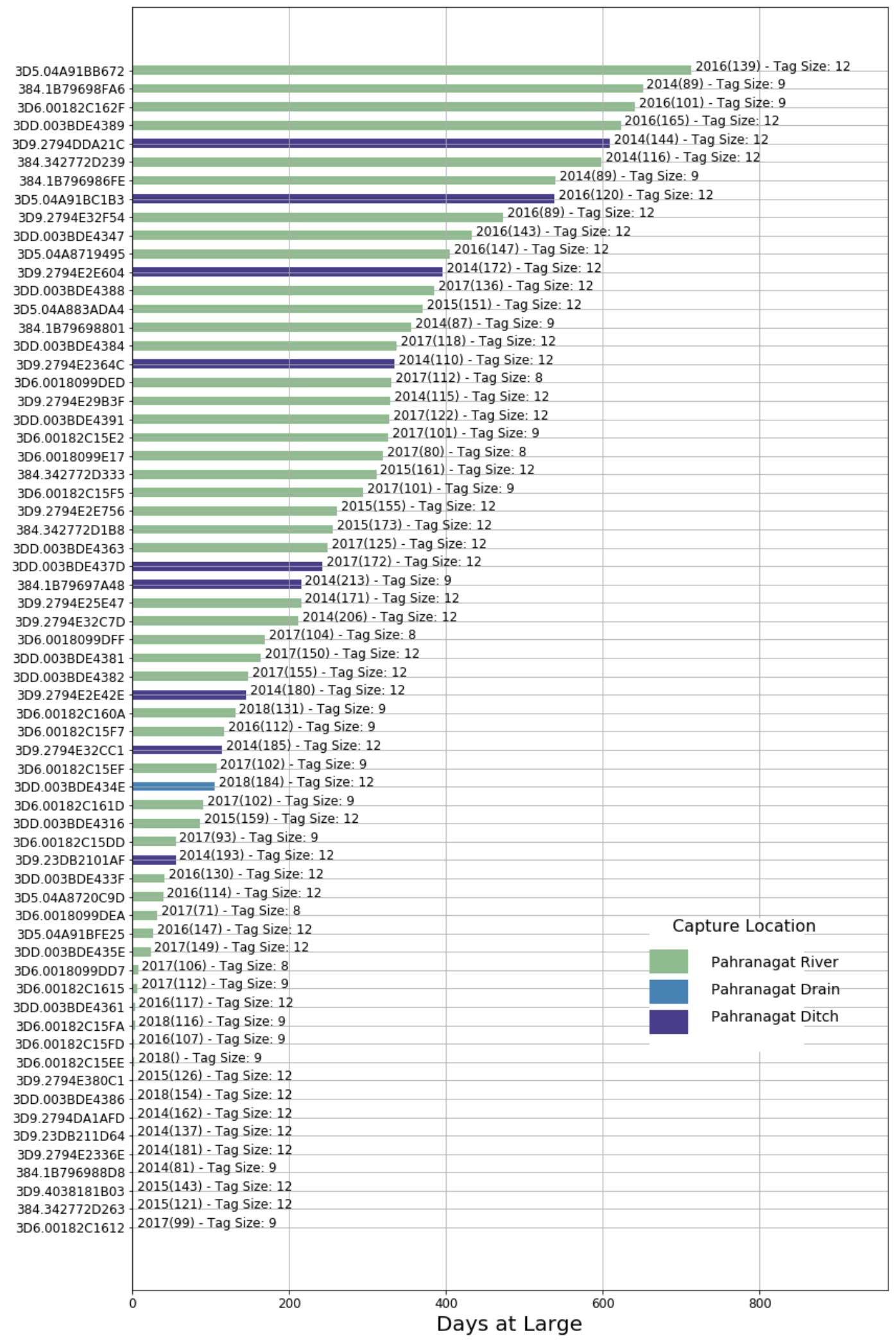

Figure 3. Graph showing number of days detected from the time of tagging to last detection (Days at Large) for individual fish color coded for reach, Pahranagat River, Nevada, 2014-18. Each bar is followed by the year tagged, total length of the fish when tagged, and passive integrated transponder tag size. Description of where fish were captured for those detected $0-1$ day after release are noted in the text. 


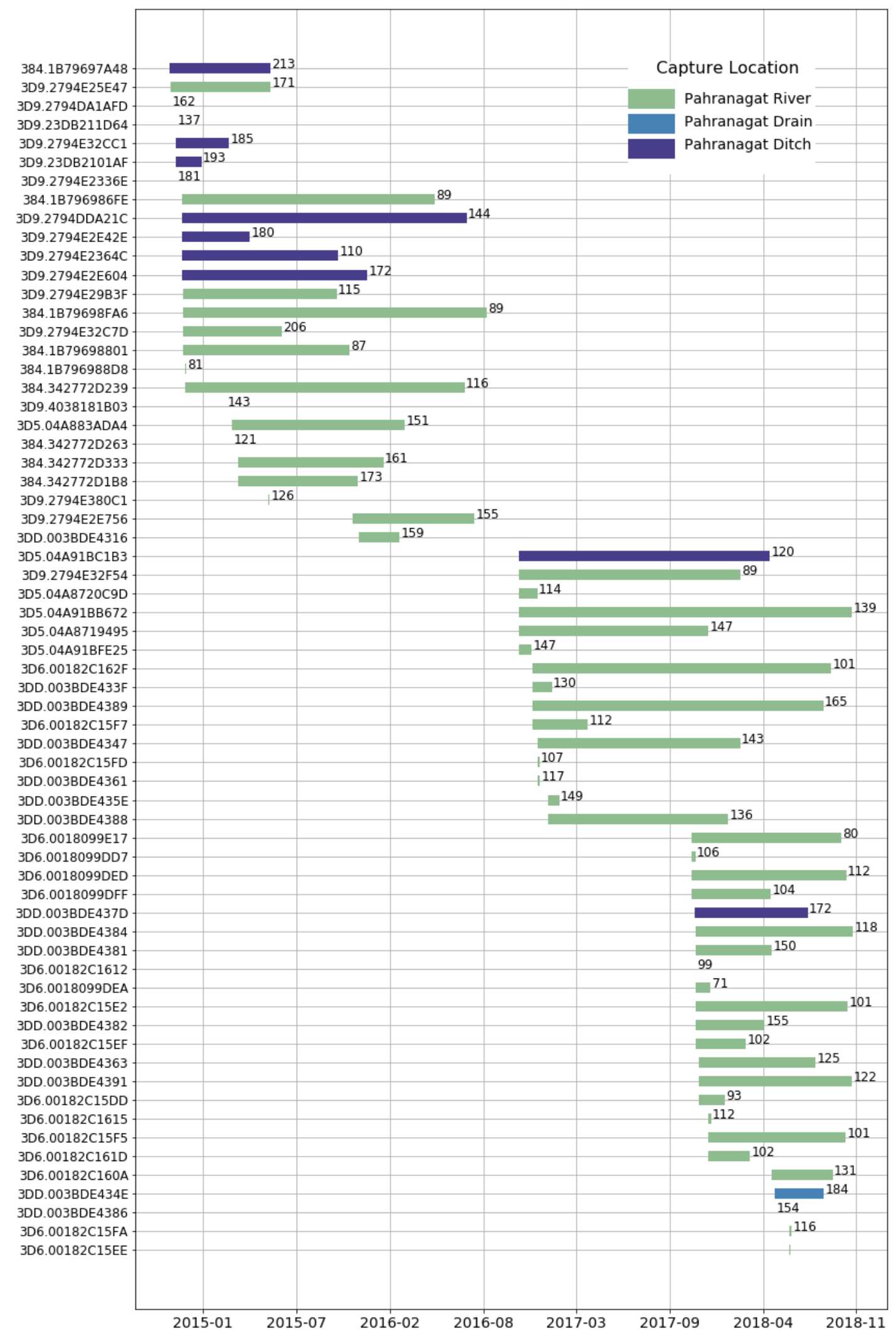

Figure 4. Graph showing time scale from time of tagging to last detection for individual Pahranagat roundtail chub (Gila robusta jordani) color coded by reach, Pahranagat River, Nevada, 2014-18. Each bar is followed by the total length of the fish at tagging. 
There was no apparent downstream migration of chub. Individual chub generally were detected in a meandering fashion with no detectable pattern to their movements (figs. 5-9). Individual chub could move from the upper portion to the lower portion of the Pahranagat River within a day. Twelve fish were detected at all five detection stations traversing the $3.5-\mathrm{km}$ distance of the Pahranagat River during the entire study (eight from the River and four from the Ditch). Five of these fish (three from the River and two from the Ditch) made the trip within 24 hours at least one time, and three of those five made the trip two to six times (two from the River and one from the Ditch). The shortest amount of time it took any fish to traverse the distance was 6 hours. Two of the fish made the round trip within 48 hours during the fall, starting and ending the trip at the Fish Passage station. Individual fish made the trip in all seasons except for summer.

A quarter of the fish (16 of 64) appeared to show site fidelity (figs. 5-9). Twelve of the River fish captured throughout the study showed site fidelity at one of three sites. Six were primarily found at the Between Bridges Station (figs. 5, 7, and 9), five at the Ash Creek station (figs. 5-7), and one at the Lower Bridge station (fig. 7). Of the River fish that showed a tendency towards site fidelity approximately half were found at the Ash Creek station and half at the Between Bridges station. An additional six River fish were only detected at the three uppermost river stations (Ash Creek, Upper Bridge, and Between Bridges). Four of the Ditch fish were primarily detected at the Lower Bridge and Fish Passage stations in equal proportions (fig. 8).

Only two of the chub appeared to show any seasonal trends towards locational preferences (3DD.003BDE4389 and 3D9.2794DDA21C). The fish originally captured in the River could be found at the three uppermost stations (Ash Creek, Upper Bridge, and Between Bridges) from December through April and at the lower two stations (Lower Bridge and Fish Passage) the remainder of the time (fig. 6). The fish originally captured in the Ditch could be found at the lower two stations (Lower Bridge and Fish Passage) year-round and were only found at the uppermost stations (Ash Creek, Upper Bridge, and Between Bridges) October through June (fig. 8). Although the majority of individuals appeared to have no seasonal location preferences, there appeared to be population level trends, with differences in primary and secondary detection locations of individual fish based on initial capture locations. Individual chubs that were captured in the Pahranagat River were most often detected on the Between Bridges antenna (table 6) followed by the Upper Bridge antenna (table 7). Those captured in the Pahranagat Ditch were most often detected at the Fish Passage array (table 6) followed by the Lower Bridge antenna (table 7). The two fish captured from the Pahranagat Drain were most often detected on the Fish Passage Array (table 6), followed by the Between Bridges antenna (table 7), the first detection for these fish was at the Between Bridges antenna where they were released. 
2014

2015

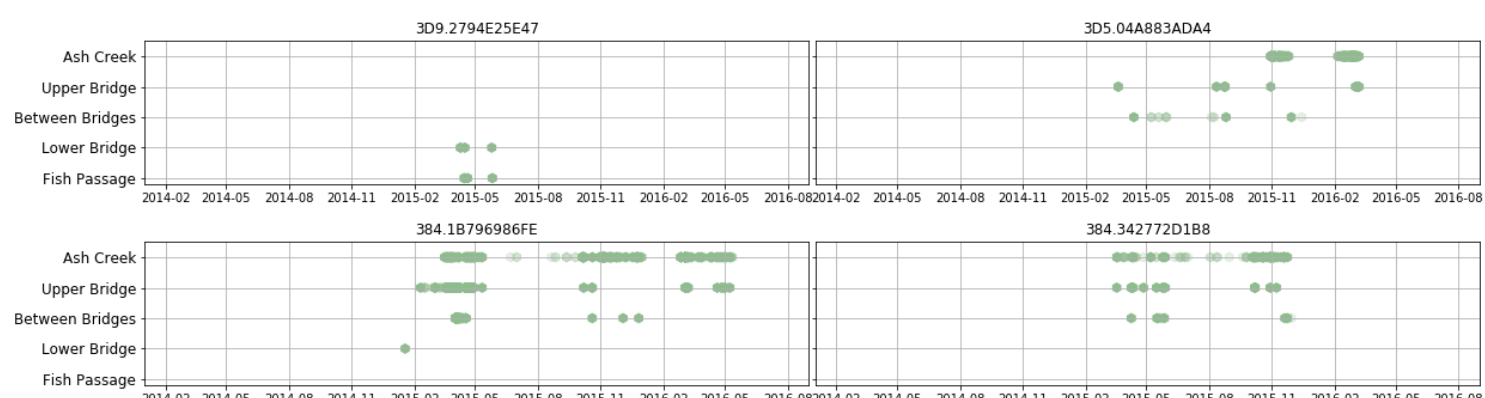

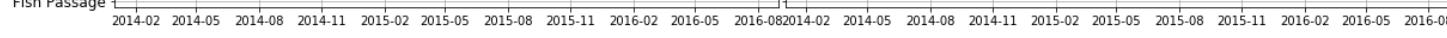

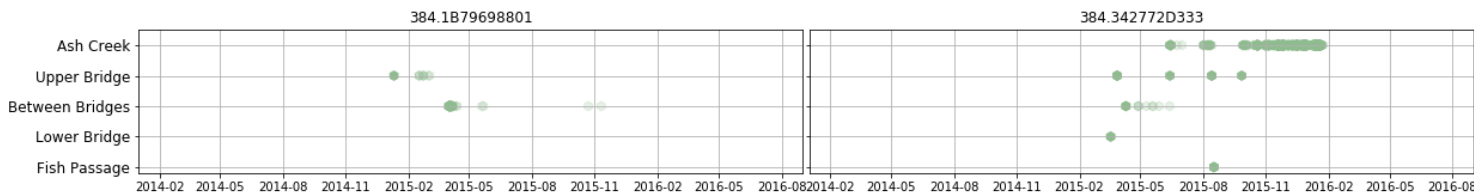
3D9.2794E32C7D 3D9.2794E380C1
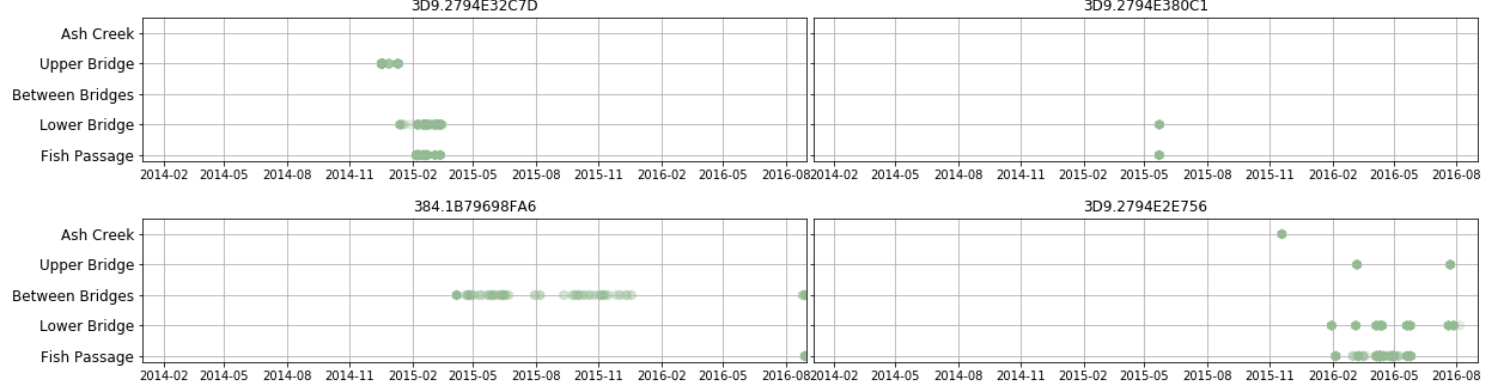

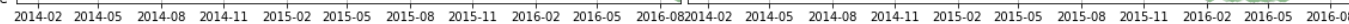

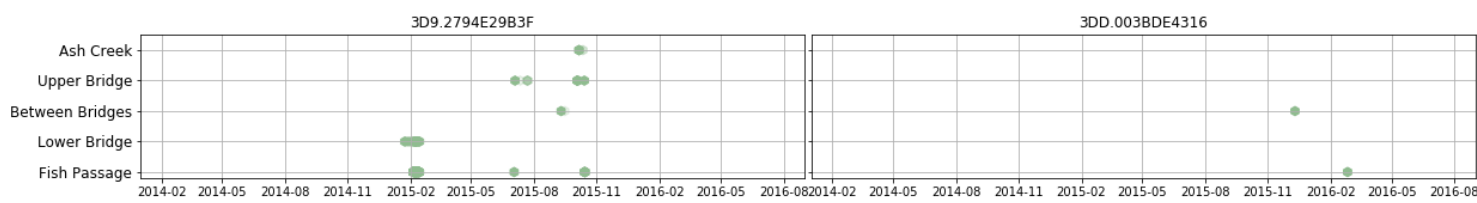
$384.342772 \mathrm{D} 239$

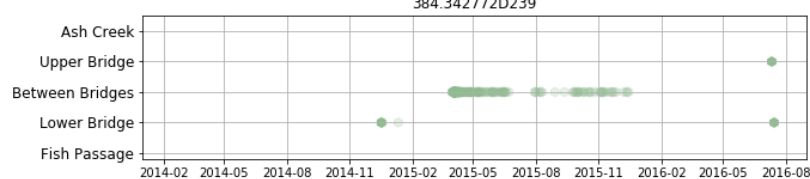

Figure 5. Graphs showing detections of individual Pahranagat roundtail chub (Gila robusta jordani) captured from the Pahranagat River, Nevada, 2014-15. 


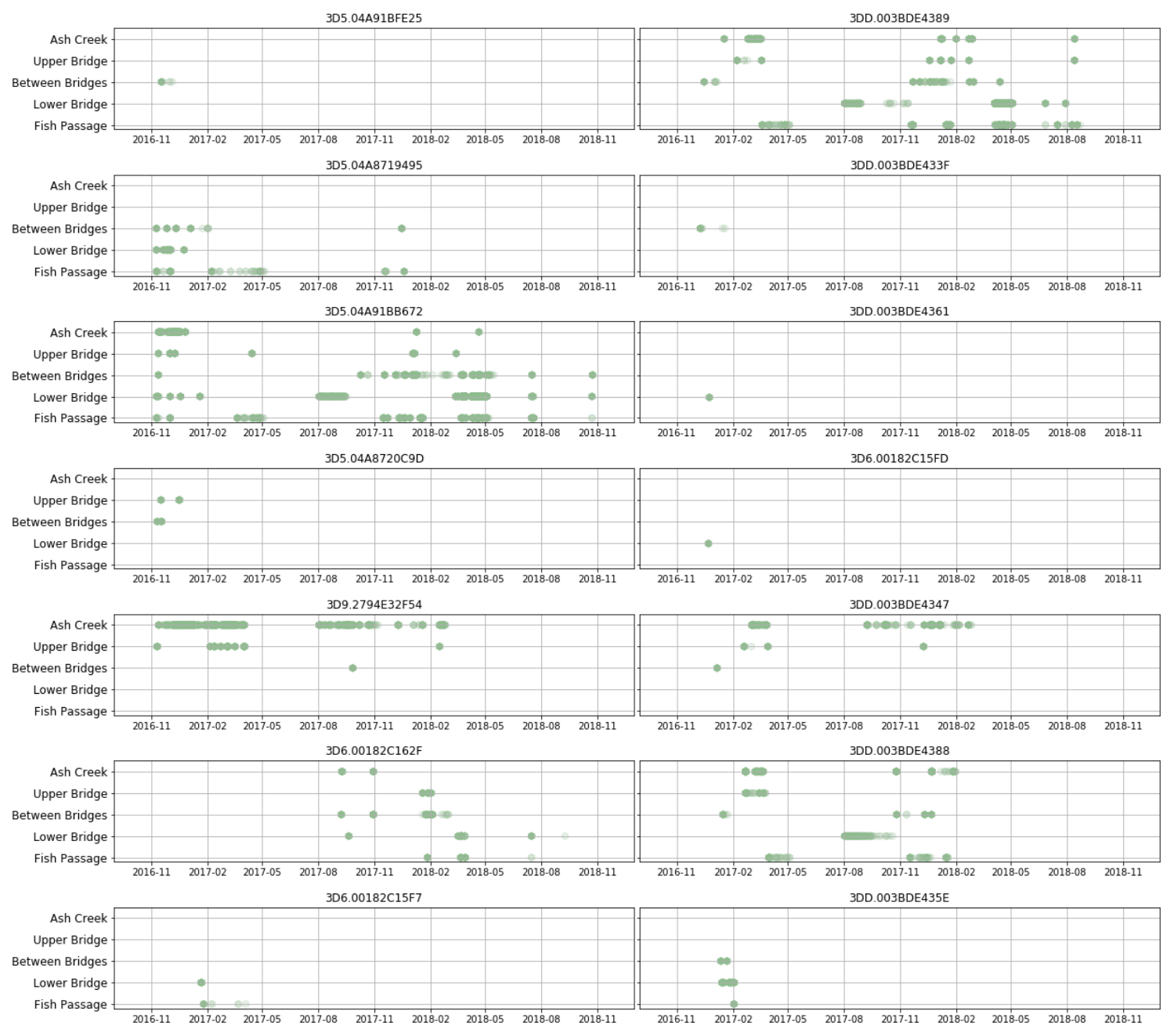

Figure 6. Graphs showing detections of individual Pahranagat roundtail chub (Gila robusta jordani) captured from the Pahranagat River, Nevada, 2016. 

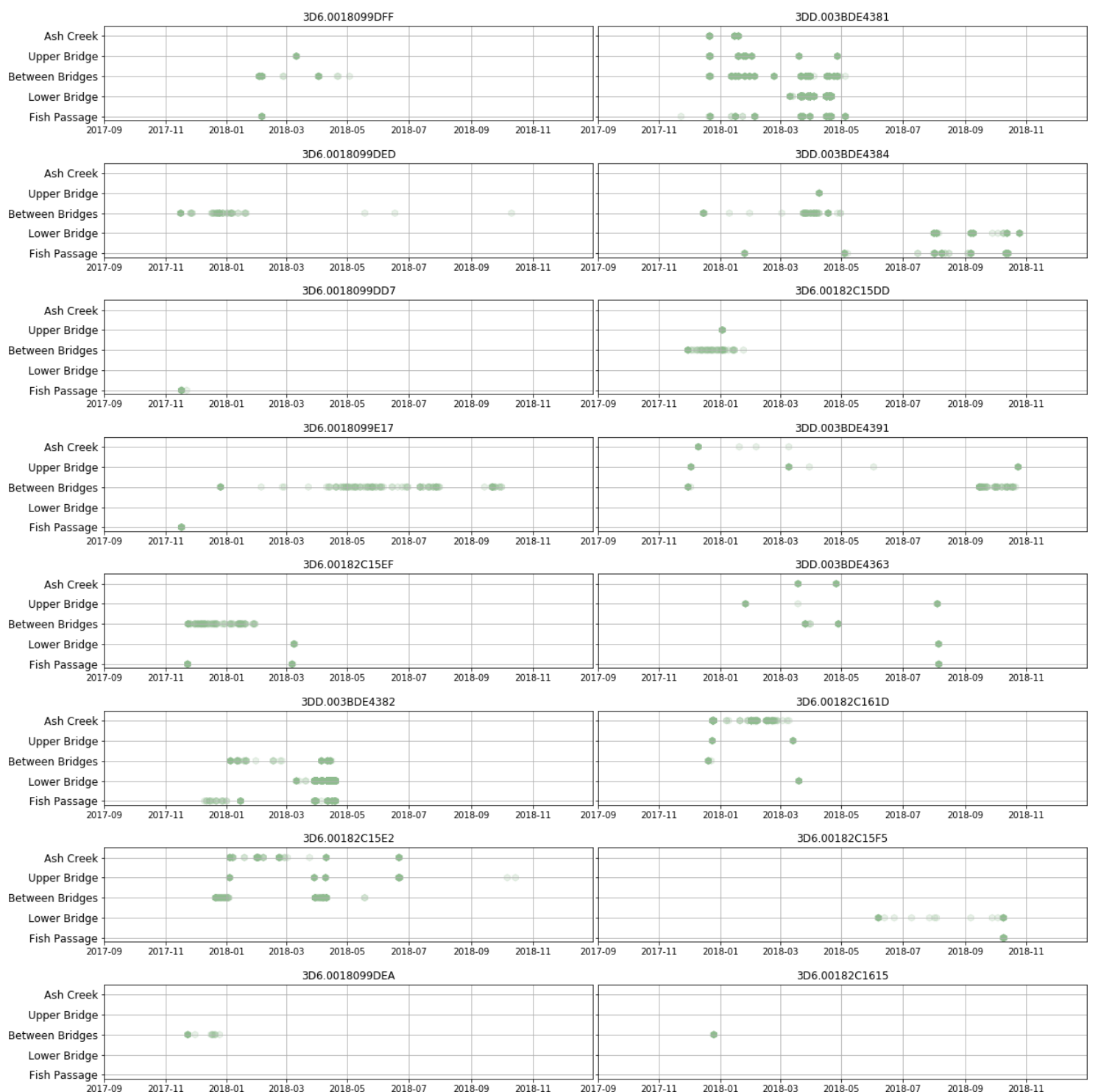

Figure 7. Graphs showing detections of individual Pahranagat roundtail chub (Gila robusta jordani) captured from the Pahranagat River, Nevada, 2017. 

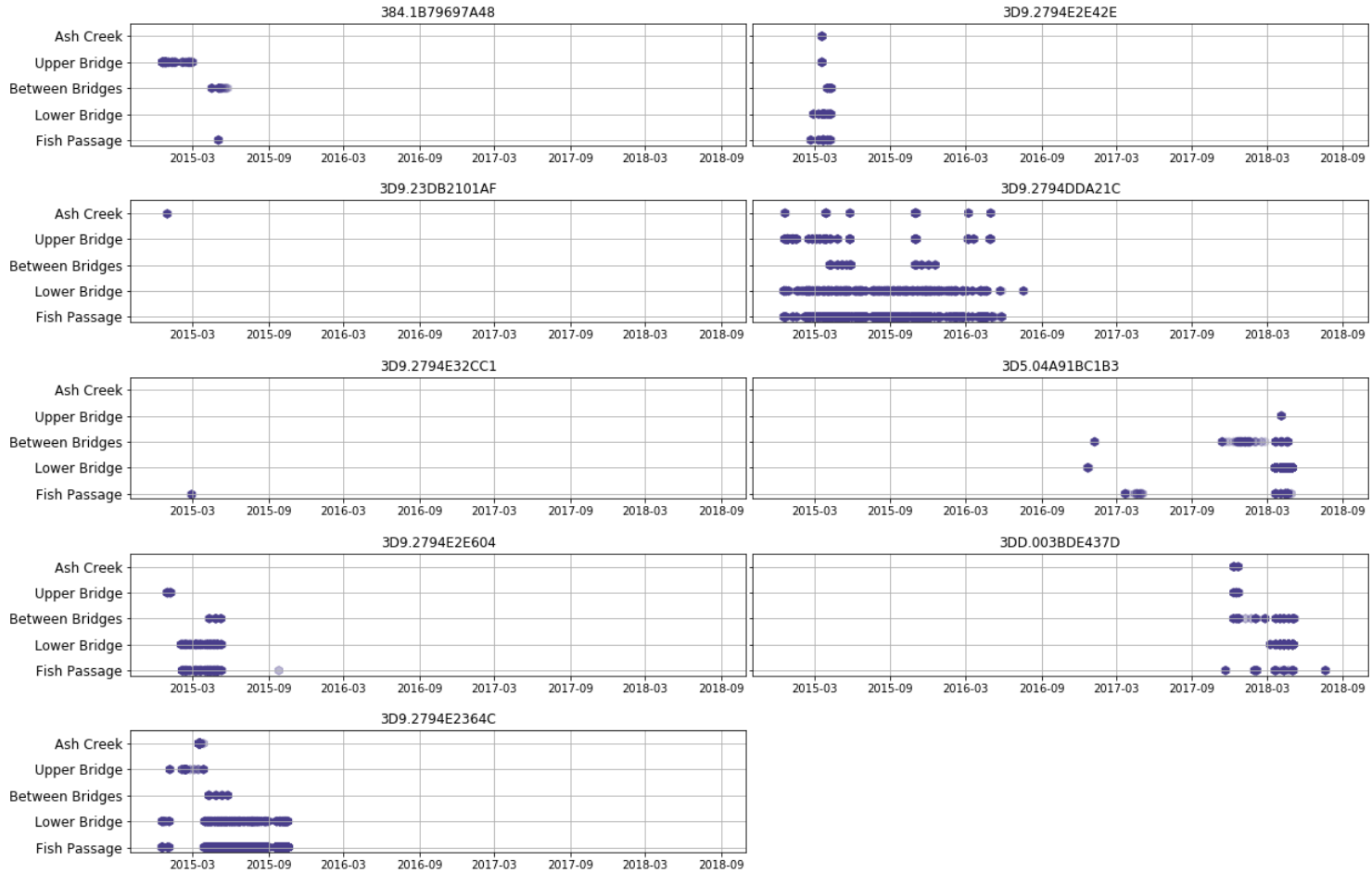

Figure 8. Graphs showing detections of individual Pahranagat roundtail chub (Gila robusta jordani) captured from the Pahranagat Ditch, Nevada, 2014-17. 


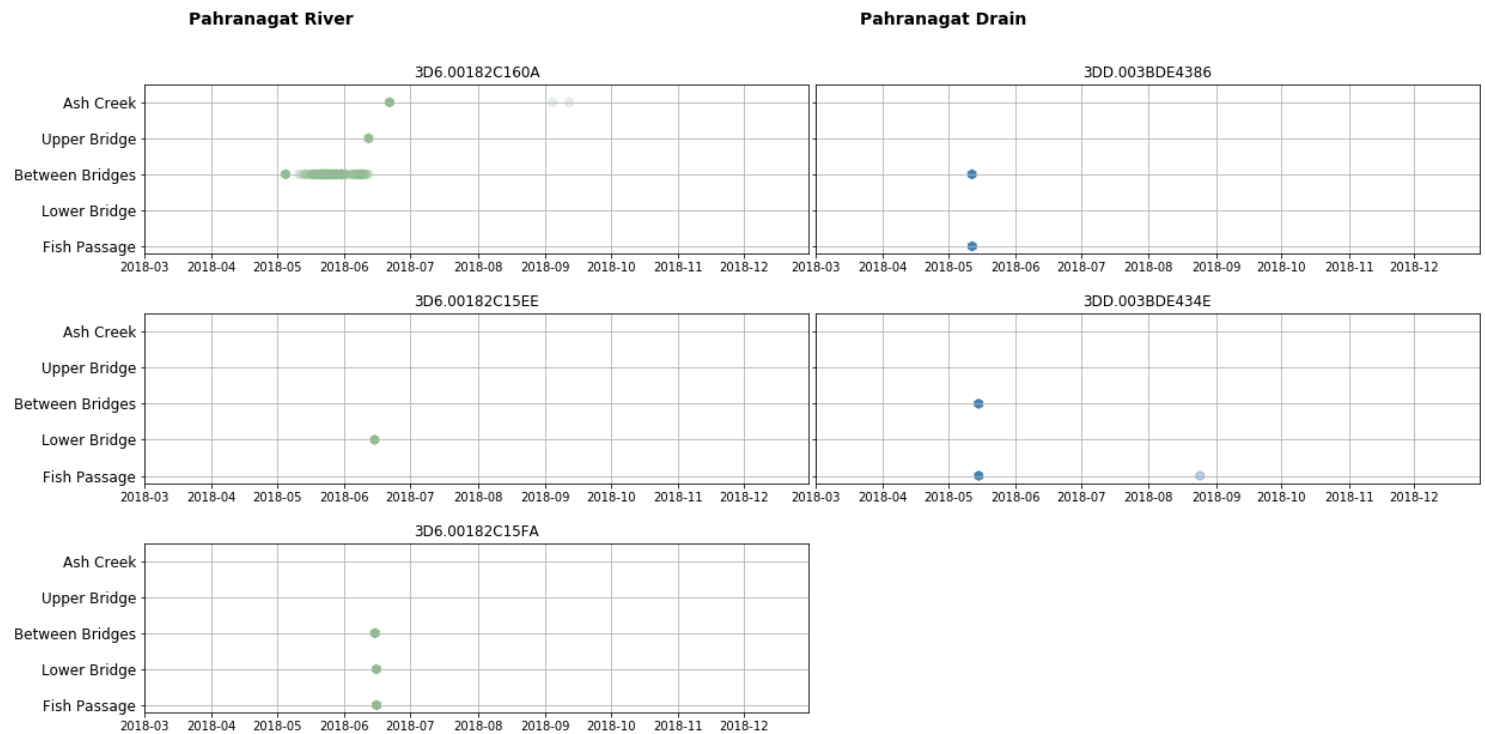

Figure 9. Graphs showing detections of individual Pahranagat roundtail chub (Gila robusta jordani) captured in 2018 from the Pahranagat River and the Pahranagat Drain, Nevada, 2014-18. Fish captured in the Pahranagat Drain were translocated to the River near the Between Bridges antenna.

Table 6. Number and percentage of chub (Gila robusta jordani) that were most often detected (their primary location) on each antenna, Pahranagat River, Pahranagat Ditch, and Pahranagat Drain, Nevada, 2014-18.

[If a fish spent an equal amount of time between two stations each station received 0.5 points instead of 1 point. Fish that were never detected were not included.]

\begin{tabular}{lllccccc}
\hline Location & $\begin{array}{l}\text { Number of } \\
\text { fish }\end{array}$ & $\begin{array}{l}\text { Ash Creek } \\
\text { (percent) }\end{array}$ & $\begin{array}{l}\text { Upper Bridge } \\
\text { (percent) }\end{array}$ & $\begin{array}{l}\text { Between Bridges } \\
\text { (percent) }\end{array}$ & $\begin{array}{l}\text { Lower Bridge } \\
\text { (percent) }\end{array}$ & $\begin{array}{l}\text { Fish Passage } \\
\text { (percent) }\end{array}$ & $\begin{array}{l}\text { Lower Ditch } \\
\text { (percent) }\end{array}$ \\
\hline River & 46 & $8(17.4)$ & $2(4.3)$ & $19.5(42.4)$ & $7(15.2)$ & $9.5(20.6)$ & 0 \\
Ditch & 9 & $1(11.1)$ & $1(11.1)$ & $2(22.2)$ & $1(11.1)$ & $4(44.4)$ & 0 \\
Drain & 2 & 0 & 0 & $0.5(25.0)$ & 0 & $1.5(75.0)$ & 0 \\
\hline
\end{tabular}

Table 7. Number and percentage of chub (Gila robusta jordani) recorded as their secondary location at each antenna, Pahranagat River, Pahranagat Ditch, and Pahranagat Drain, Nevada, 2014-18

[If a fish spent an equal amount of time between two or more stations as their secondary location, each station received an equal number of a percentage of a point instead of a point. Fish that were never detected or only detected at one station are not included.]

\begin{tabular}{lllccccc}
\hline Location & $\begin{array}{l}\text { Number of } \\
\text { fish }\end{array}$ & $\begin{array}{l}\text { Ash Creek } \\
\text { (percent) }\end{array}$ & $\begin{array}{l}\text { Upper Bridge } \\
\text { (percent) }\end{array}$ & $\begin{array}{l}\text { Between } \\
\text { Bridges } \\
\text { (percent) }\end{array}$ & $\begin{array}{l}\text { Lower Bridge } \\
\text { (percent) }\end{array}$ & $\begin{array}{l}\text { Fish Passage } \\
\text { (percent) }\end{array}$ & $\begin{array}{l}\text { Lower Ditch } \\
\text { (percent) }\end{array}$ \\
\hline River & 36 & $3(8.3)$ & $11.5(31.9)$ & $4.5(12.5)$ & $9(25.0)$ & $8(22.2)$ & 0 \\
Ditch & 7 & $1(14.3)$ & $0.3(4.7)$ & $1(14.3)$ & $2.3(33.3)$ & $2.3(33.3)$ & 0 \\
Drain & 1 & 0 & 0 & $1(100)$ & 0 & 0 & 0 \\
\hline
\end{tabular}


The majority of fish that were detected at the Fish Passage array were detected on the Pond antenna $(\mathrm{F}-1 ; \mathrm{N}=34)$, followed by the Upper Ditch antenna $(\mathrm{F}-2 ; \mathrm{N}=25)$, and the Upstream Barrier antenna $(\mathrm{F}-3 ; \mathrm{N}=24)$. Very few fish were detected at the Downstream Barrier antenna $(\mathrm{F}-4 ; \mathrm{N}=8)$ or the Upper Drain antenna (F-5; N=5). The fish detected at the Upper Drain were previously detected at the Downstream Barrier which in turn were previous detected at the Upstream Barrier. The eight fish that traversed the Fish Passage Barrier, made a total of 32 round trips, with 9 of those trips detected on the Upper Drain antenna. Most of the fish traversed the Fish Passage Barrier from November through mid-March when the gate allowing flow to the Drain was fully open. There were two exceptions: fish 3D9-2794E2E756 was detected crossing the Fish Passage Barrier during April 2016 while fish 3D504A91BB672 crossed the Fish Passage Barrier in April 2017 and April and May 2018. All the fish that were detected at the Upper Ditch antenna were previously detected at the Pond antenna. The chub that were initially captured in the Pahranagat River and found on the Fish Passage array were more likely to be found at the pond at the head of the ditch (F-1) or at the top of the Fish Passage Barrier (F-3; table 8). The chub that were initially captured in the Ditch and detected on the Fish Passage arrays were more likely to be found at the Pond at the head of the Ditch (F-1) or in the Upper Ditch (F-2; table 8). The chub captured at the Drain were only detected at the two arrays associated with the Ditch (F-1 and F-2) and not those associated with the Drain (F-3, F-4, F-5; table 8).

Table 8. Number of Pahranagat roundtail chub (Gila robusta jordani) detected by capture location at each of the five antennas within the Fish Passage Array, Pahranagat River, Pahranagat Ditch, and Pahranagat Drain, Nevada, 2014-18.

[Fish that were never detected are not included]

\begin{tabular}{lllcccl}
\hline Location & Number of fish & F-1 (percent) & F-2 (percent) & F-3 (percent) & F-4 (percent) & F-5 (percent) \\
\hline River & 46 & $25(54)$ & $17(37)$ & $19(41)$ & $6(13)$ & $3(7)$ \\
Ditch & 9 & $7(78)$ & $7(78)$ & $5(56)$ & $2(22)$ & $2(22)$ \\
Drain & 2 & $2(100)$ & $1(50)$ & 0 & 0 & 0 \\
\hline
\end{tabular}

There was no pattern as to the array of last detection compared to initial tagging location (table 9). Only two fish were detected on the Lower Ditch antenna, for both fish, this was their last detection. Another 16 fish were last detected at the Fish Passage array: 1 at Upstream Barrier (F-3; Ditch fish), 9 at the Pond (F-1; 2 initially from the Drain and one from the Ditch), and 6 in the Upper Ditch (F-2; all initially from the River). Although these fish could have stayed in the Ditch, other chub were detected on the Fish Passage array and then later detected at upstream locations. There were no fish that were last detected at the Downstream Barrier (F-4) or Upper Drain (F-5) antennas. This indicated that fish that had been located below the Fish Passage Barrier were able to transverse the Fish Passage Barrier back upstream to the Pahranagat Ditch or River.

Table 9. Number of Pahranagat roundtail chub (Gila robusta jordani) by capture location that were last detected at each passive integrated transponder tag station, Pahranagat River, Pahranagat Ditch, and Pahranagat Drain, Nevada, 2014-18.

[Chub that were never detected or only detected on one antenna are not included]

\begin{tabular}{lllccccc}
\hline Location & $\begin{array}{l}\text { Number of } \\
\text { fish }\end{array}$ & $\begin{array}{l}\text { Ash Creek } \\
\text { (percent) }\end{array}$ & $\begin{array}{l}\text { Upper Bridge } \\
\text { (percent) }\end{array}$ & $\begin{array}{l}\text { Between Bridges } \\
\text { (percent) }\end{array}$ & $\begin{array}{l}\text { Lower Bridge } \\
\text { (percent) }\end{array}$ & $\begin{array}{l}\text { Fish Passage } \\
\text { (percent) }\end{array}$ & $\begin{array}{l}\text { Lower Ditch } \\
\text { (percent) }\end{array}$ \\
\hline River & 46 & $6(13)$ & $4(9)$ & $11(24)$ & $12(26)$ & $12(26)$ & $1(2)$ \\
Ditch & 9 & $1(11)$ & 0 & $2(22)$ & $3(33)$ & $2(22)$ & $1(11)$ \\
Drain & 2 & 0 & 0 & 0 & 0 & 2 & 0 \\
\hline
\end{tabular}


The overall activity level of all of the chubs combined indicated that the fish were generally not very active during summer months, with the exception of 2015 (figs. 10-11). Generally, 2015 had more detections at all stations during all seasons (fig. 10). In 2015, chub appeared the most active in and around the Fish Passage array during all seasons except for fall (fig. 10). Ash Creek had the highest detections compared to the other stations during winter (except for 2015) and fall (fig. 10). Detections during spring were not dominated by any particular station throughout the years (fig. 10). Furthermore, during spring and summer chub were generally not active during daylight hours (fig. 11). In November and December chub were noticeably active during the entire 24-hours, while during winter and October chubs appeared to have intermittent activity during daylight hours compared to the other seasons (fig. 11).
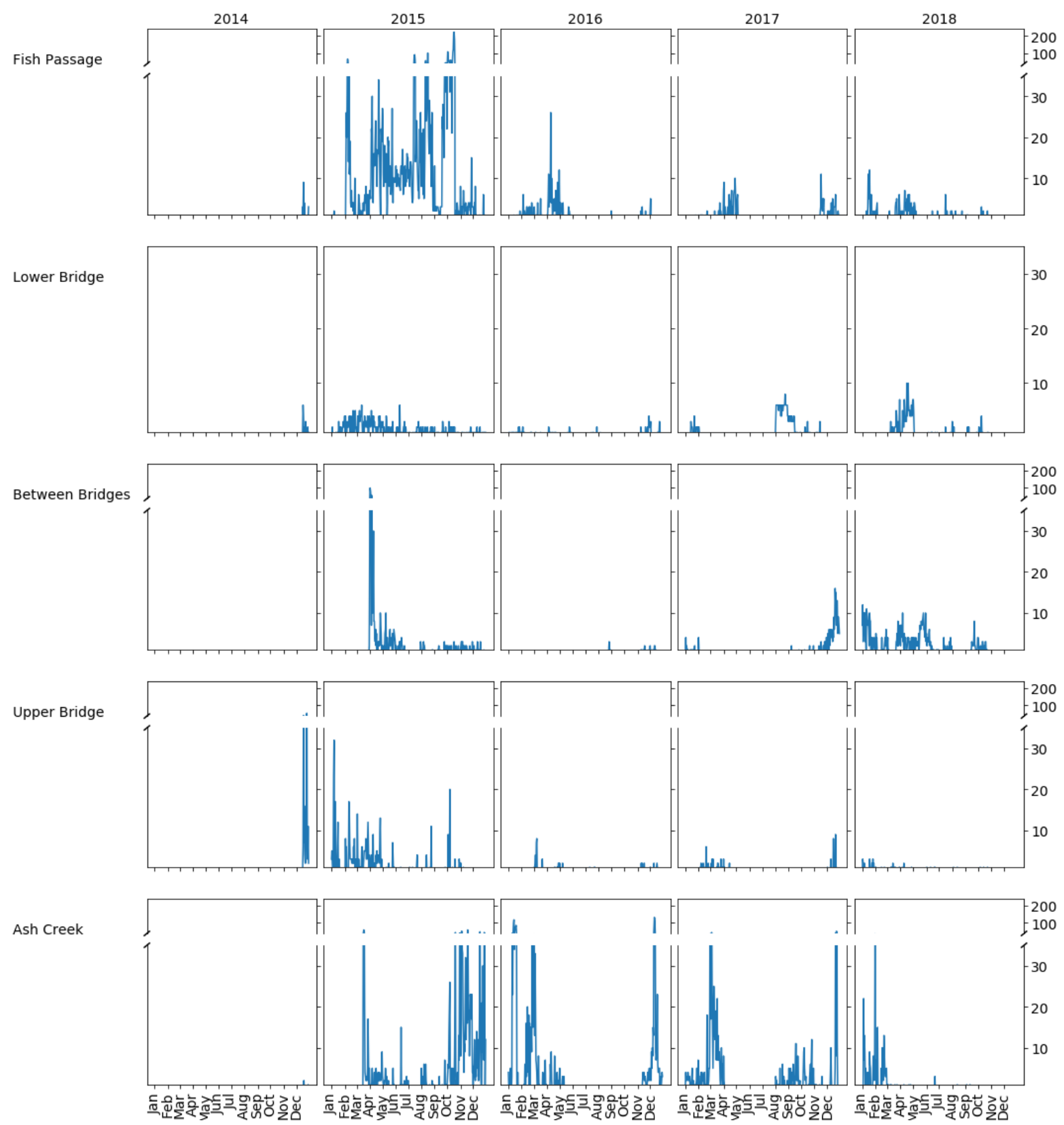

Figure 10. Graphs showing population level detections of Pahranagat roundtail chub (Gila robusta jordani) by year, month, and station, Pahranagat River, Pahranagat Ditch, and Pahranagat Drain, 2014-18. 

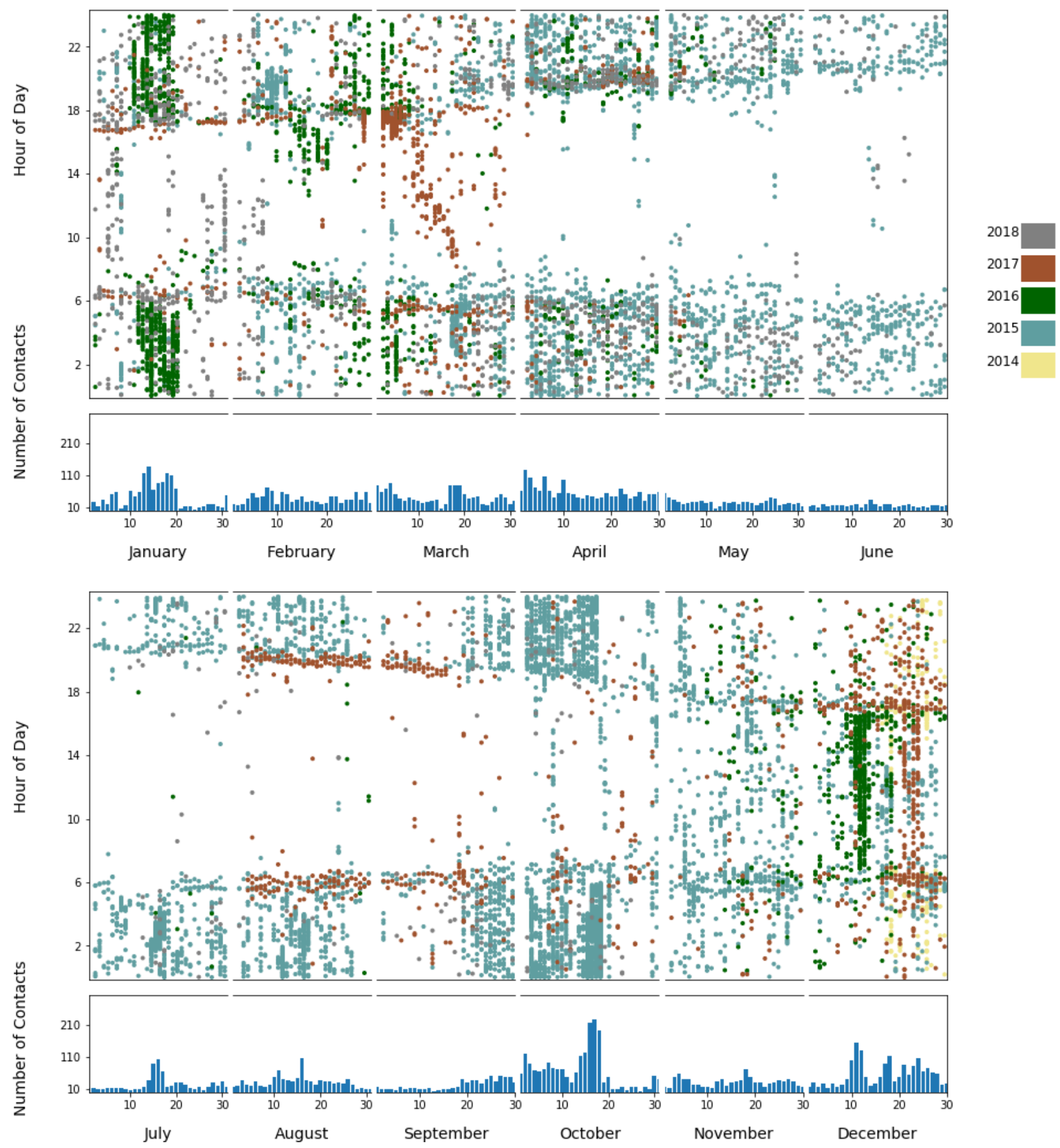

Figure 11. Graphs showing population level diel contacts of Pahranagat roundtail chub (Gila robusta jordani), Pahranagat River, Pahranagat Ditch, and Pahranagat Drain, 2014-18. Hourly points are coded by year.

\section{Discussion}

Our study was the first study to look at movements of individual chub through their known distribution range using individually PIT-tagged fish. Past studies were mainly focused on habitat use observed through snorkel surveys (Tuttle and others, 1990; Guadalupe and Madill, 2012; Guadalupe, 2014). Through the tracking of individual chub we observed that about a quarter of the individuals appeared to show site fidelity, an occurrence that had not been observed in past studies. A quarter of 
the chub captured in the River were primarily found in the upper sections of the Pahranagat River. Likewise, a quarter of the chub captured in the Ditch appeared to have site fidelity to the lower section of the Pahranagat River and the pond associated with the Pahranagat Ditch. This study found that, at the population level, fish captured in the River were more likely to be detected on the Between Bridges antenna but fish captured in the Ditch were more likely to be detected on the Fish Passage array. Therefore, this study also suggests some site fidelity at the population level, collaborating our findings at the individual level. Hardy's (1982) observation that individual fish with distinctive markings were continuously found in the deep pond near the Fish Passage station during the summers of his 2-year study may have also indicated that chub show site fidelity. Furthermore, Hardy (1982) found most of the fish in his study left the deep pool near the Pahranagat Ditch in February and March returning in April, presumably they left the pond for spawning. Hardy (1982) did not observe the location to which the chub migrated; however, Tuttle and others (1990) noted that the chub in Hardy's study most likely traveled to a spawning location between the two bridges.

Spawning congregations have been primarily observed at three Pahranagat River locations, all between the two bridges (U.S. Fish and Wildlife Service 1998). However, in 2018, Fish and Wildlife Service documented a large spawning congregation by the Ash Creek antenna station (James Harter, U.S. Fish and Wildlife Service, written commun., 2019). Adults begin to congregate in mid-January and spawn from late January through mid-February with congregates disbanding at the end of March (Tuttle, 1990). Snorkel surveys in May have indicated that most of the chubs in the Between Bridges area have been juveniles (Guadalupe and Madill, 2012; Guadalupe, 2014). Consequently, past surveys indicating that chubs were most often found during the winter between the two bridges was more than likely tracking the spawning aggregation. Our assessment of individual chub detections during the winter were not as definitive with individuals meandering from one detection station to another and no pattern of primary detection site over the years. However, activity level based on number of detections on an antenna summarized among all individuals does indicate activity is greater during the winter and spring at the upper locations in the river. Furthermore, our assessment of diel movement patterns indicates that fish are more active during all hours during winter and spring.

Past snorkel surveys indicated seasonal variation in distribution of Pahranagat roundtail chub, with chubs found most often between the Upper Bridge and the Lower Bridge during fall and winter and during the summer they were found between the Lower Bridge and the Fish Passage, primarily in the two large deep pools in the lower reaches, suggesting seasonal downstream migration (Hardy, 1982; Tuttle and others, 1990; Guadalupe and Madill, 2012; Guadalupe, 2014). We saw this trend with two of the four chub that showed any indication of seasonal migration in our study (both initially captured in the River); however, the other two fish showed a different trend of mainly being located at the Fish Passage and Lower Bridge site most of the year and traveling upstream during October-June (both initially captured in the Ditch). Hardy (1982) found chub prefer deep, slow runs and pools and hypothesized chub may prefer temperatures less than $25^{\circ} \mathrm{C}$. Furthermore, Tuttle and others (1990) found that warmer temperatures caused large chubs (greater than $175 \mathrm{~mm}$ ) to go downstream, suggesting seasonal downstream migration. The average length of the chubs captured in the three reaches during our study indicate that the larger fish were captured downstream with smaller and presumedly younger fish found upstream supporting Tuttle and others (1990) observations of larger fish in downstream locations. However, our observations of fish size in conjunction with location were not related to temperature. We did not observe seasonal migrations on the population level during this study; however, we did observe seasonal and annual variation in activity level. Furthermore, we did not observe that individual fish were primarily detected in one location or another at a given point in time. Instead, we found the fish meandered often using the entire $3.5 \mathrm{~km}$ of the River, sometimes moving from one end of the River to the other within a day. One fish made the $3.5 \mathrm{~km}$ trip in 6 hours. Therefore, as mentioned above, even though past studies based on snorkel surveys have found the majority of fish to be located in different areas by season, this study did not corroborate those results. 
Even though we did not observe seasonal migrations in this study, we did observe that temperature had an effect on the movements of individual chub. We found that activity level decreased during the summer when temperatures increased. Furthermore, during daylight hours, summer activity levels were almost nonexistent. We noted that chub were not observed traversing the entire $3.5 \mathrm{~km}$ of the River during the summer, whereas they often made the trip during other seasons. During 2015 we found individual chub more active than any other year and attributed this increased activity to lower temperatures during spring, summer, and fall of 2015. Temperatures in Hiko, Nevada (National Weather Service, 2018), during these seasons for 2015 were about $5{ }^{\circ} \mathrm{C}$ cooler than in those seasons during 2016-18.

Other researchers have hypothesized that increased summer temperatures are the major cause of mortality in juvenile chub (Hardy, 1982; Tuttle and others, 1990). Although there may have been a mortality event of our adult PIT-tagged chub in fall 2016, only a small portion of the tagged chub were detected past mid-summer, indicating that the mortality may have been due to natural attrition and not extreme conditions. No unusual temperature events occurred in late summer or early fall 2016 for Hiko, Nevada, compared to 2017 or 2018 , that would point to a mortality event caused by the climate in 2016 and not in the other 2 years. Consequently, the loss of detection of the remainder of the tagged chub in August 2016 was more likely attributed to natural mortality and not some catastrophic event or emigration out of the system.

We found the majority of last detections occurred during winter suggesting increased winter mortality of the older chubs used in our study. The increased mortality may be partially due to the age of the fish. This study verified that chub can live at least 3 years as at least one age- 1 chub was tagged and tracked for over 2 years. Furthermore, Hardy (1982) observed several adult chub with distinctive markings throughout his 2-year study, which suggests that the individuals can live at least 3 years. However, there is no direct evidence from our study or previous studies indicating individuals of the species living for more than 3 years. Although our study suggests adult chub are more likely to perish during the winter, other studies have shown a decrease in juvenile chub numbers during the summer. Tuttle and others (1990) observed a drop-off in chub numbers between summer and fall, indicating that the high temperatures during the summer likely cause higher mortality in juveniles. Furthermore, Hardy (1982) found that juveniles disappeared rapidly from September through January, indicating either increased mortality or emigration for the juveniles as well during the same time frame. Every year, juvenile chub utilize the drain from October through March, indicating that some of Hardy's decline in juvenile numbers may have been emigration into the drain.

Fish and Wildlife Service and Nevada Department of Wildlife conduct annual recovery efforts to capture and relocate chub when the water is diverted from the Pahranagat Drain to the Pahranagat Ditch during the irrigation season. These efforts usually result in the relocation of juvenile chub which often will use the upper part of the Pahranagat Drain as habitat (Cody Anderson, U.S. Fish and Wildlife Service, written commun., 2019). However, occasionally adult chub are also captured as in May of 2018. We detected several chub traversing the Fish Passage Barrier in both directions during this study; however, they usually crossed the structure when the gate was fully open allowing for regular flow entering the drain. In 2016, 2017, and 2018, PIT-tag chubs were detected crossing the Fish Passage Barrier after mid-March when the gate above the Fish Passage Barrier is at least partially closed. During 2016 and 2017, chubs crossed the Fish Passage Barrier as late as mid-April, whereas in 2018 they crossed the Fish Passage Barrier as late as mid-May. Although the irrigation district often starts closing the gate on March 15th, there is usually too much water at that time, so instead they close the gate in stages using different configurations of boards that varies from year to year depending on water levels. Generally, the gate is completely closed by late May, and once the gate is completely closed no fish should be able to traverse the Fish Passage Barrier (Christina Manville, U.S. Fish and Wildlife Service, written commun., 2019). Because none of the PIT-tagged chubs last detection was below the Fish Passage Barrier, we assume that none of the PIT-tagged chubs exited the system via the 
Drain. However, because there are more juveniles captured in the Drain during the annual salvage operations, there is always the possibility that juvenile chub not salvaged are stranded in the Drain and subsequently perish.

Although two of our PIT-tagged chub likely exited the system through the lower section of the Ditch, there was no indication that chub exited the system via the Ditch on a regular bases. Of the 16 PIT-tagged chub last detected at the Fish Passage array, 6 were last detected on the Ditch antenna below the pond. Four of these six fish were only detected on the F-2 antenna once, as their last detection, and therefore may have exited through the lower Ditch if the Lower Ditch antenna happened to be down when these fish passed the station. Although the remaining two fish could have moved downstream to the Lower Ditch, they were detected on this F-2 ditch antenna and then later detected upstream 6 and 27 times for each fish. Additional chub were detected upstream after being recorded as many as 321 times on the F-2 antenna. Consequently, it is unlikely that additional PIT-tagged chubs exited the system via the Ditch.

Since it is unlikely that chub regularly exit the system through the Drain or the Ditch, there must be another explanation as to the limited numbers of chub in the system. The known habitat of the chub is quite limited, with only $3.5 \mathrm{~km}$ of the Pahranagat River still in use and apparently only a small portion of the Drain and the Ditch is used. Past researchers have hypothesized that food and quality space may be a limiting factor for the chub (Hardy, 1982; Tuttle and others, 1990). Tuttle and others (1990) hypothesized that adult chub preferred the habitat of the two deep pools, located in the Pahranagat Ditch, during the summer due to their cooler temperatures, but some chub occupied areas upstream in the Pahranagat River due to limited space and resources in the pools. Tuttle and others (1990) indicated that the use of habitat from Ash Creek to Upper Bridge was less consistent and they attributed this to the intermittent occurrence of enhanced foraging opportunities in the cool water from the inflow of Crystal Springs. Tuttle and others (1990) observed there was a greater amount of available prey items in this area during the winter with periodic availability during the summer. We also noted that detections on the Ash Creek antenna were more prevalent during the winter and almost nonexistent during the summer supporting Tuttle's observations. Furthermore, Tuttle and others (1990) hypothesized that distinctive hydrologic conditions to which chub were attracted enhance their encounters with prey. Therefore, it is possible the system has a carrying capacity that is limited by available preferred habitat and food.

\section{Acknowledgments}

Data were provided by the U.S. Geological Survey Reno Field Station and Klamath Falls Field Station, the U.S. Fish and Wildlife Service, and Nevada Department of Wildlife.

\section{References Cited}

Guadalupe, K., 2014, Nevada Department of Wildlife native fish and amphibians field trip report: Las Vegas, Nevada, Nevada Department of Wildlife, 7 p.

Guadalupe, K., and Madill, S., 2012, Nevada Department of Wildlife native fish and amphibians field trip report: Las Vegas, Nevada, Nevada Department of Wildlife, 8 p.

Hardy, T.B., 1982, Ecological interactions of the introduced and native fishes in the outflow of Ash Spring, Lincoln County, Nevada: Masters Thesis, University of Nevada, Las Vegas, 99 p.

Miller, R.R., and Hubbs, C.L., 1960, The spiny-rayed cyprinid fishes (Plagopterini) of the Colorado River system: Miscellaneous Publications of the Museum of Zoology University of Michigan, no. 115, p. 1-39.

National Weather Service, 2018, NOWData-NOAA online weather data: National Weather Service, https://w2.weather.gov/climate/xmacis.php?wfo=vef. 
Sigler, W.F., and Sigler, J.W., 1987, Fishes of the Great Basin-A Natural History: University of Nevada Press, Reno, Nevada, 425 p.

Tanner, V.M., 1950, A new species of Gila from Nevada (Cyprinidae): The Great Basin Naturalist, v. 10 , no. 1 , article 2.

Tuttle, P., Scoppettone, G., and Withers, D., 1990, Status and life history of Pahranagat River fishes: Seattle, Washington, U.S. Fish and Wildlife Service, National Fisheries Research Center, 51 p.

U.S. Fish and Wildlife Service, 1970, Conservation of endangered species and other fish or wildlife: Federal Register, v. 35, no. 165, p. 13519-13520.

U.S. Fish and Wildlife Service, 1998, Recovery plan for the aquatic and riparian species of Pahranagat Valley: Portland, Oregon, U.S. Fish and Wildlife Service, Region 1, 82 p.

U.S. Fish and Wildlife Service, 2014, Pahranagat roundtail chub (Gila robusta jordani): Nevada Fish \& Wildlife Office, U.S. Fish and Wildlife Service, https://www.fws.gov/nevada/protected_species/fish/species/pahranagat_roundtail_chub.html. 
Publishing support provided by the U.S. Geological Survey Science Publishing Network, Tacoma Publishing Service Center

For more information concerning the research in this report, contact the Director, Western Fisheries Research Center

U.S. Geological Survey 6505 NE 65th Street

Seattle, Washington 98115-5016

https://www.usgs.gov/centers/wfrc 


\section{$\frac{\mathbb{2}}{\mathrm{C}}$}

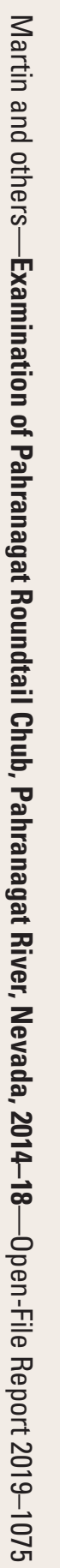

